\title{
Building a community for sexual orientation and gender identity rights in ASEAN
}

Edition 6, 2021

Professor Meredith Weiss

DOI: 10.37839/MAR2652-550X6.9

Time and again, incidents marked by hyperbolic, sensationalist, and often eroticised reactions by media, politicians, and others show how pervasive resistance to the rights of sexual orientation and gender identity and expression (SOGIE) is across much of Southeast Asia.

Malaysia, for instance, has recently seen the vilification of a transgender cosmetics entrepreneur facing charges under syariah law of cross-dressing. She appears to have fled the country after evading an 'overzealous' police dragnet and social-media threats of violence or death. That case follows on a series of others, from luridly reported raids on gay venues to the highly public spectacle of Malaysia's first-ever caning of women for lesbian sex. Even comparatively progressive and rights-aware states in the region, such as Timor-Leste, the only Southeast Asian state Freedom House currently rates as 'free', cannot be counted on to include SOGIE rights among those they protect. It would make sense for local activists to seek out other forums, if only for solidarity and strategies.

Here, I assess the extent to which the Association of Southeast Asian Nations (ASEAN) - a regional inter-governmental grouping with a still fairly recentlyenhanced human rights agenda and apparatus-provides a useful forum for SOGIE advocacy and of what sort; the potential trade-offs such efforts entail; and what might develop, moving forward, given rather unpropitious domestic human-rights 
trends overall in the region.

\section{ASEAN's partial embrace of human rights}

In many ways, ASEAN's gradual adoption of a human-rights agenda since the 1990s, and especially over the past decade, has been innovative and even surprising. An organisation with non-intervention at its core and a history of tolerating even highly abusive regimes has institutionalised standards and a commission that implicitly acknowledge certain rights as, in the words of the ASEAN Human Rights Declaration, 'universal, indivisible, interdependent and interrelated'. Each person, it declares, 'is entitled without discrimination to equal protection of the law', with minimal limitations on the 'exercise of human rights and fundamental freedoms'-albeit with deference to 'regional and national context'. Establishment of the ASEAN human rights body, the ASEAN Intergovernmental Commission on Human Rights (AICHR), in 2009 came after more than 40 years' association and a decade's discussion. Pushing the envelope was not just the 2007 ASEAN Charter's promise of a 'human rights body', but also political liberalisation in key member states and shocks that made clear the multidimensionality, extending plausibly to rights, of human security and development.

However, the ASEAN Human Rights Declaration does not validate all rights equally. In particular, sexuality rights did not make the final cut. The Declaration does bar discrimination on grounds of 'other status' and protects 'vulnerable and marginalised groups', offering a possible toehold for groups not named, but to include SOGIE rights would extend beyond the rights most states in the region currently articulate. Even so, it lays the groundwork, making eventual recognition of SOGIE rights at least more imaginable than previously. 


\section{SOGIE rights advocacy in ASEAN: The state of play}

Domestic tolerance for any rights advocacy varies across the region, and not all ASEAN member-states have vibrant or even visible SOGIE rights-advocacy communities. Interestingly, a ranking of states per SOGIE mobilisation or protections would align poorly with one of political liberalism. Vietnam and Myanmar, for instance, have made significant recent headway in organising and recognition; Singapore has a well-organised community notwithstanding criminalisation of gay sex and lesbian, gay, bisexual, and transgender (LGBT) groups being denied legal registration; Indonesia faces unprecedented state and societal hostility. The Philippines has arguably made the greatest progress, to the extent of pride marches, queer student organisations on university campuses, and even the world's first LGBT political party; yet legal protections remain unimpressive. Whether the issue is repressive states' 'pinkwashing' or sexuality rights falling prey to parties' efforts to rally their base in purportedly more democratic states, political liberalisation is neither required for, nor guarantee of, protection of SOGIE rights. This less than propitious landscape limits the potential for domestic organising-even if, given divergent cultural and political contexts, advocates for specific claims (e.g., addressing provisions of syariah rather than secular law) might prefer to focus their efforts at the state level. It also makes clear a disconnect with much SOGIE organising in western liberal democracies, given their different starting point for social and state acceptance and accommodation.

Importantly, by now, the acronym 'LGBT' is increasingly official and common parlance region-wide, however awkward its fit with local manifestations or counterpart indigenous terms. The shift more recently in Asia toward language of 'SOGIE' (or 'SOGISC', substituting 'sex characteristics' for 'expression'), at least in regional and international forums, effectively queers the categories L/G/B/T and moves away from neatly demarcated bins. That said, 'SOGIE' shifts the focus from 
individuals as, for instance, being an ' $\mathrm{L}$ ' or a ' $\mathrm{G}$ ' (notwithstanding the occasional Southeast Asian politician's quirky reference to 'SOGIE people') to a set of characteristics; the label may thus be less useful as an identity tool, as well as being less known outside academic and activist circles. ('Queer' itself serves a similar purpose, by subsuming all who are non-normative or gender-variant, albeit via a term with pejorative historical connotations and a comparatively radical mien.)

Most central to an examination of regional SOGIE rights advocacy is a regional platform called the ASEAN SOGIE Caucus, alongside complementary efforts under the ASEAN Intergovernmental Commission on Human Rights. Activists from all member states except Brunei and Laos formed the ASEAN SOGIE Caucus in 2011 as an offshoot of the ASEAN Civil Society Conference/ASEAN People's Forum. The previous year's ASEAN Peoples Forum conference statement first raised SOGIE issues; the subsequent Forum hosted an inaugural LGBTIQ ASEAN Regional Meeting. That effort produced a set of LGBT-relevant recommendations and a call in the final conference statement for ASEAN member states to repeal direct or indirect criminalisation and pathologisation of SOGIE; recognise and promote SOGIE rights as human rights; harmonise national policies and praxis with the 2006 Yogyakarta Principles on sexual orientation and gender identity (amended and expanded in 2017 as the 'Yogyakarta Principles plus 10'); and ensure equal access to social services and healthcare.

The activists involved decided to organise as the ASEAN SOGIE Caucus. The Caucus brings together a range of SOGIE-related civil-society organisations in ASEAN member states, as well as some individuals (primarily from countries lacking relevant associations), under the leadership of a regionally constituted steering committee and board of trustees, plus a Philippines-based secretariat. The Caucus calls for SOGIE-inclusive frameworks and plans of action; domestic legal protection and empowerment of, and state/non-state engagement with, LGBT civil society; and ensuring at least the comparatively democratic states in the region make headway toward recognising the range of human rights and civil liberties. 
Although ASEAN has yet to take up any of the proposals the SOGIE Caucus has submitted, the Caucus has worked with the National Human Rights Institutions that underlay the ASEAN Intergovernmental Commission on Human Rights, a few of which (particularly in Indonesia, the Philippines, and Thailand) have been at least somewhat receptive to including SOGIE issues. Indeed, some National Human Rights Institutions from ASEAN-member and other Asia-Pacific states have been proactive in addressing SOGIE-related discrimination since the launch of the Yogyakarta Principles. For instance, in 2017, the Asia Pacific Forum of National Human Rights Institutions produced a guide for best-practice for integrating a SOGIE focus as part of human rights work broadly. Others, though, have made less headway with such efforts; the political and social roadblocks remain substantial. All told, although the ASEAN SOGIE Caucus has focused to a significant extent on trying to improve guidelines and laws specific to SOGIE within ASEAN and pressuring member states to pass and/or uphold such provisos, both domestic and regional, they do so knowing that policy advocacy may prove frustratingly fruitless.

Meanwhile, presenting LGBT-specific issues as inextricable from broader political ones and hoping to 'mainstream' a SOGIE perspective, the ASEAN SOGIE Caucus has also collaborated with civil-society organisations from across the region to issue statements on relevant issues in member states: for instance, on proposed revisions to Indonesia's criminal code and their implications for sexual-orientation and gender minorities; on punishments for consensual sex and restrictions on bodily autonomy under Brunei's syariah code; and on workplace harassment of the LGBT community in Myanmar. The Caucus has mobilised during the COVID-19 pandemic, too, for a needs assessment with LGBT organisations in the region and to determine community-specific impacts of the pandemic and state responses to it. (The period has been challenging: lockdown measures in particular have adversely impacted the informal and gig economies in which many LGBT individuals work, being shut in with family members who reject or disrespect them has added to the risks many face, and contact-tracing surveillance measures as well as medical screenings raise concerns of outing and discrimination.) All told, the specific issues on which the 
Caucus has mobilized do engage explicitly with matters of gender and sexuality, but they also represent larger political campaigns and offer opportunities for crossmovement solidarity.

And yet, much of the ASEAN SOGIE Caucus's energy and progress has less to do with policies than with building solidarity.

\section{The risks and rewards of regionalised rights advocacy}

A key achievement of ASEAN-level SOGIE activism is, essentially, groundwork: establishing a network and consolidating resources. ASEAN serves in these efforts more as domain of engagement than the target of claims. This conceptualisation suggests that regional institutions and processes create strategic and discursive resources that the organisation itself cannot control. Human rights protection, including SOGIE rights, must depend on more than just ASEAN and its specific (limited) commitments. SOGIE Caucus activists are neither reliant on nor especially hopeful for a proactive ASEAN role in SOGIE rights governance, yet they purposefully orient around mainstreaming LGBT human rights and claiming space within the Association.

The issue for ASEAN is really less about laws on the books than attitudes on the ground. A recent study in Singapore, for instance-which has more secular governance than most states in the region, and a highly educated and internationally exposed population-found a majority believe sex between two adults of the same sex to be always (61.6 percent) or almost always (18.4 percent) wrong. Only 5.6 percent thought it 'not wrong at all', lower than the usual rule-of-thumb 10 per cent who are themselves LGBT. Tolerance decreases with age, but two-thirds even of those at the youngest end of the scale, 18-25 years old, at least almost always reject same-sex relations. Those numbers notwithstanding, Singapore has formally foresworn enforcing its anti-sodomy laws (however adamant about keeping them on 
the books) and has been home to the increasingly massive, business-sponsored 'Pink Dot' sexuality-rights event annually for a decade; the narrative here is complex. Moreover, a second, independent survey in Singapore found 60 percent favoured retaining section 377A of the Penal Code, which criminalises sex between men, and that overall support for the law actually increased once respondents learned of the government's policy of retaining, but not enforcing the law. These data suggest nonenforcement to be 'an acceptable compromise'-and that 'negative' opinions about same-sex relations may or may not translate into support for criminal sanctions-regardless of the stigma and intrinsic rights violation that retaining the law entails.

Nor may Southeast Asian SOGIE rights advocates enjoy full, free space for protest and claim-making, to change laws or to encourage revision of disparaging social attitudes. Their activism may need simultaneously to work within and push the boundaries of social norms, while both evading and reforming legal restrictions on critical participation. This daunting domestic environment poses a key challenge for the ASEAN SOGIE Caucus's regional advocacy, but also recommends a focus less on instrumental policy-change (still important to the Caucus's mission) than on more expressive, solidarity-building goals, useful for strengthening a movement, building capacity, capitalising on economies of scale (for tasks from strategising to translation), and distributing risk within and across Southeast Asian states.

\section{The way forward}

It is still quite new for international documents-for instance, UN statements and covenants-to include SOGIE rights. It was only in 2012 that the UN High Commissioner for Refugees explicitly articulated sexuality-rights assurances and state obligations toward LGBT people, following a 2011 report, and, writes sociologist and queer theorist Momin Rahman, 'queer rights ... have only recently and inconsistently become legitimate credentials of modernisation in the West'. Even just a few years prior to that point, sentiment at the UN General Assembly was too 
divided for the body to offer majority backing for a statement affirming LGBT rights, though then-Secretary General Ban Ki Moon asserted such support in 2010. Opposition and abstentions left even the success of the 2011-12 initiative far from assured.

Yet the international arena is changing, offering at least tentative normative support in many intergovernmental and international organisations for SOGIE rights, and stimulating innovative strategising. The UN itself has taken definitive steps to institutionalise attention to these rights, mandating in 2016 an Independent Expert on protection against violence and discrimination based on sexual orientation and gender identity; the first incumbent was Thai professor of international and humanrights law (and co-chair of the Yogyakarta Principles' drafting committee), Vitit Muntarbhorn. Transnational activism spurs and shapes both issue emergence and issue framing in the domestic context. The seemingly perverse balance between ASEAN states' intransigence and activists' outspoken persistence reflects the benefits of safety in numbers, as those facing greater threat align themselves with likeminded others with more room for manoeuvre.

The reality is, state responses range from reactive to proactive or pre-emptive; and societal responses may do the same. Not only might activists be able to sidestep to some extent the recoil against 'LGBT' by shifting to a discourse of 'SOGIE', but also, SOGIE advocates in especially unwelcoming states can hone their skills and strategic thinking by working in or on behalf of ASEAN neighbours in a less pre-emptively hostile state. Alternatively, they might offer dismissively homophobic elites' Southeast Asia-derived doctrines and discourse to prove their point that the ideas they espouse are indigenous, and appropriate.

Both what LGBT human rights includes and how international NGOs (including bodies such as the ASEAN SOGIE Caucus) construct and promote within that category warrants clarification. In the short- to medium-term, one might look to the ASEAN SOGIE Caucus as a space for conceptualisation and movement-building-for definition and pursuit of expressive and affective goals, regardless of the 
opportunities for, and critical of the limitations of, policy achievements within member states. Such objectives may echo and amplify normatively oriented domestic programs pitched more at 'LGBT dignity, self-respect, and fair treatment' than just rights per se, but scale up the effort and diffuse it regionally. Given that scale, while the ASEAN SOGIE Caucus does plan solidarity actions together with member-state civil society organisations (with which Caucus activists are also involved), more of the effort to define specific steps toward empowerment at the personal or community level remains the domain of those sorts of local or national organisations. As for ASEAN-the ASEAN Intergovernmental Commission on Human Rights, and the ASEAN Human Rights Declaration-there seems no reason to expect a dramatic shift toward protection of SOGIE rights in a formal sense, and given the structure of laws and sovereignty in the region, ASEAN mechanisms would have limited authority, regardless.

However, the fact of ASEAN's human-rights premises has arguably seeded a platform for discussion and solidarity. The institutions and processes ASEAN has crafted opportunities that ASEAN itself cannot control-ASEAN's architecture comes to legitimate work that may diverge even fairly sharply from its founders' and present-day leaders' intentions. As political scientist Karen Zivi suggests,

'... the democratic potential of rights claiming lies not necessarily in the laws or policies it engenders or in bringing closure to a particular political debate but in the fact that it allows individuals silenced by illness, class, race, and other factors [in this case, sexuality and gender identity] to unite and engage in acts of democratic citizenship that shift the very meaning of democratic community.'

While these SOGIE rights claims are not only about claiming space within an ASEAN community, their performance may become part and parcel of the melange of 'rituals and symbols' by which, international relations expert Matthew Davies posits, 'ASEAN creates the impression of unity in the absence of other unifiers'. Indeed, the ASEAN SOGIE Caucus itself has accumulated visibility, recognition, and alliances over time-a record on which ongoing efforts at outreach, advocacy, capacity- 
development, and awareness-raising aim to build. But in the process, putting these extra-marginalised rights on the table and obliging ASEAN to dismiss them obliquely acknowledges and certifies the community presenting these claims: a response requires a purposeful step of accepting or rejecting, rather than ignoring or remaining oblivious to those claimants.

How seriously ASEAN takes its commitment to human rights, or how inclusive the roster of rights it recognises, is almost beside the point; deep socio-political differences among member states, as well as societal rather than merely political homophobia, counsel against our putting too much store in legal rights, regardless. But if ASEAN as institution is unlikely to see its way toward SOGIE rights, the arena it reifies arguably helps activists navigate frames and strategies, as they work toward building community and validating a complex, fraught mix of identities on the ground. What matters is less ASEAN as a set of institutions to be lobbied than the space and impetus ASEAN provides for solidarity-building regional mobilisation; ASEAN becomes more a passive setting than protagonist in this advocacy story, at least for now. In the process, however unexpectedly, the ASEAN SOGIE Caucus's effort exemplifies just the sort of 'people-centred' focus and regional identitybuilding ASEAN doctrine claims to seek, but among a subset of the regional community ASEAN as a whole opts not to acknowledge and protect.

This article draws on interviews with Southeast Asian rights activists and is adapted from an article published in the March 2021 issue of Asian Studies Review.

Image: Pride March and Festival, Manila, 2019. Credit: Metro Manila Pride. 